\title{
Kawasaki and COVID-19 disease in children: a systematic review
}

\author{
Daura Faustino Gonçalves ${ }^{1}$ \\ (iD) Ana Inês Gonzales 2 \\ Fernanda Soares Aurélio Patatt ${ }^{3}$ \\ (iD) Karina Mary de Paiva ${ }^{4}$ \\ (iD) Patrícia Haas ${ }^{4}$
}

1. Graduanda em Fonoaudiologia pela Universidade Federal de Santa Catarina - UFSC, Florianópolis, SC, Brasil 2. Doutora e Fisioterapeuta UDESC - Universidade do Estado de Santa Catarina, Florianópolis, SC, Brasil 3. Doutora pela Universidade de Brasília (UnB), Brasília, DF, Brasil 4. Professora Doutora do Curso de Fonoaudiologia pela Universidade Federal de Santa Catarina - UFSC, Florianópolis, SC, Brasil

http://dx.doi.org/10.1590/1806-9282.66.S2.136

\section{SUMMARY}

OBJECTIVE: To present scientific evidence based on a systematic literature review (PRISMA) evaluating the association of Kawasaki Disease (DK) and COVID-19 in children.

METHODS: For the selection of studies, a combination based on the Medical Subject Heading Terms (MeSH) was used. The Medline (Pubmed), LILACS, SciELO, COCHRANE, and BIREME databases were used. The search period for the articles comprised the last 10 years (2010 to 2020).

RESULTS: 840 articles with potential for inclusion were retrieved, one of which met the inclusion criteria and the guiding question that consisted of evaluating the association of Kawasaki disease and COVID-19 in children.

CONCLUSION: A significant increase in the incidence of Kawasaki-type diseases after the onset of the epidemic has been reported, suggesting an association between the COVID-19 epidemic and the high incidence of a severe form of KD. However, further studies are needed to conduct an investigation of the association between these two diseases.

KEYWORDS: Mucocutaneous Lymph Node Syndrome; Coronavirus infections; Kid; Vasculitis; Kawasaki Disease; COVID-19

\section{INTRODUCTION}

Kawasaki Disease (KD), first described in 1967, is characterized by a multisystemic disorder with acute inflammatory processes in small and medium vessels, particularly in the coronary arteries ${ }^{\mathbf{1 , 2}}$. If left untreated, it can lead to several complications and even sudden death'. KD affects predominantly children, usually younger than 5 years old, and is the second most common vasculitis in this population, with a risk 1.5 times higher of occurring in boys than in girls; however, it is considered rare in children younger than 6 months old ${ }^{1}$.

The epidemiological patterns of $\mathrm{KD}$ are quite 
distinct regarding geographical location, with different incidence values between continents. In the countries of northeast Asia, including Japan, South Korea, China, and Taiwan, the incidence is 10 to 30 times higher than in the United States and Europe, with indices that have been increasing continuously ${ }^{1,3,4}$. In the USA, the incidence of KD is estimated to be between 17.5 and 20.8 per 100,000 children aged less than 5 years, while in Canada it is 19.6 per 100,000. Whereas in Europe it is around 5 to $10 / 100,000^{3.4}$.

The diagnosis of KD is a clinical challenge, given its large variety of signs and symptoms since it may resemble other viral and bacterial infections ${ }^{1}$. In this sense, the clinical diagnosis is achieved by identifying signs and symptoms, as well as using various laboratory parameters that can complement the final diagnosis ${ }^{5}$.

Some parameters are considered at the time of the diagnosis, such as the presence of fever for five or more days, accompanied by chapped lips, cervical lymphadenopathy, erythema, or polymorphic rash ${ }^{6}$. Given the high rate of cardiac complications from this disease, cardiac biomarkers are used for diagnostic purposes ${ }^{1}$. Heart sequelae are mainly related to the coronary arteries. For these patients, regular monitoring by imaging is paramount, and techniques such as myocardial perfusion imaging, angiography, and, more recently, magnetic resonance imaging are ideal ${ }^{1,7}$.

Medical reports have described the presence of a hyperinflammatory response resulting from viral infection by the novel coronavirus (COVID-19) in children, with changes in the coronary arteries similar to KD. The hypotheses presented indicate that some children might be genetically predisposed to a more robust inflammatory response to the virus. These recent findings demonstrate the need for further efforts in order to elucidate the reasons behind these outcomes, which remain unknown ${ }^{8}$.

The incidence of COVID-19 worldwide has significantly increased and accelerated. To date, 215 countries, areas, or territories have reported cases and over 254,000 deaths have been attributed to the virus, in addition to over 4 million confirmed cases ${ }^{9}$.

Although it is still early to confirm the association between KD and COVID-19 infections, studies show the incidence of KD cases during spring and winter, suggesting its association with some types of viral infections, such as those by adenovirus, enterovirus, parvovirus, rhovírus, varicella, Epstein Barr, measles, and dengue ${ }^{10-24}$. Studies have described an association between viral respiratory infections and $\mathrm{KD}$, ranging from $9 \%$ to $42 \%$ of patients with a positive test for viral respiratory infection within 30 days before the diagnosis of $\mathrm{KD}^{15,25-27}$.

An initial analysis of the data obtained from adult patients with COVID-19 in China showed a significant increase with high rates of cardiac troponin, a parameter that is associated with an increase in mortality. It has been reported that, in COVID-19 patients, the microvascular damage in the heart cause perfusion effects, vessel hyperpermeability, and vasospasm, leading to myocardial injury ${ }^{28}$.

Faced with the current pandemic and the uncertainties still generated around the association between KD and COVID-19 infections, this systematic review aims to present the scientific evidence available, up until now, about the association between Kawasaki Disease and COVID-19 in children.

\section{METHODS}

Research characterization and search strategies

A systematic review was conducted according to the recommendations of the Preferred Reporting Items for Systematic Reviews and Meta-Analyses (Prisma) ${ }^{29}$.

The searches for scientific articles were carried out by two independent researchers in the Medline (PubMed) (https://www.ncbi.nlm.nih.gov/pubmed/), Lilacs (http://lilacs.bvsalud.org/), SciELO (http://www. scielo.br/), Cochrane (https://www.cochrane.org/), and Bireme (https://bvsalud.org/) electronic databases, with no language or location restrictions, from April to May 2020.

The research was structured and organized according to the PICO methodology, which is an acronym for Population, Intervention, Control, Outcomes, Study (Table 1).

TABLE 1. DESCRIPTION OF THE PICOS COMPONENTS

\begin{tabular}{l|l} 
Acronym & Definition \\
\hline$P$ & Children \\
\hline $\mathrm{I}$ & Kawasaki Disease \\
\hline $\mathrm{C}$ & Association \\
\hline $\mathrm{O}$ & Coronavirus \\
\hline $\mathrm{S}$ & $\begin{array}{l}\text { Descriptive study/Cross-sectional study } \\
\text { Observational study }\end{array}$ \\
\hline
\end{tabular}

Source: Prepared by the authors.

The descriptors were selected from the dictionary 
the Health Sciences Descriptors (DeCS) and Medical Subject Heading Terms (MeSH). The following keywords and boolean operators were proposed for the searches: [((kawasaki syndrome)) AND ((COVID19) OR (Coronavirus disease)) AND ((children)) AND ((randomized controlled trial[pt] OR controlled clinical trial[pt] OR randomized controlled trials[mh] OR random allocation[mh] OR double-blind method[mh] OR singleblind method[mh] OR clinical trial[pt] OR clinical trials[mh] OR ("clinical trial"[tw]) OR ((singl*[tw] OR doubl*[tw] OR trebl*[tw] OR tripl*[tw]) AND (mask*[tw] OR blind*[tw])) OR ("latin square"[tw]) OR placebos[mh] OR placebo*[tw] OR random*[tw] OR research design[mh:noexp] OR follow-up studies[mh] OR prospective studies[mh] OR cross-over studies[mh] OR control*[tw] OR prospectiv*[tw] OR volunteer*[tw]) NOT (animal[mh] NOT human[mh])).

The use of the keywords and boolean operators was adjusted according to the databases searched. As a complement, a manual search was carried out in the references of the papers included in the search, and gray literature was searched on Google Scholar.

\section{SELECTION CRITERIA}

Inclusion criteria

The designs of the studies selected included descriptive studies, randomized or non-randomized controlled clinical trials, cross-sectional studies, cohort studies, and case studies. We included studies with no language or location restrictions, published from January 2010 to May 2020.

\section{Exclusion criteria}

Were excluded studies published in the format of letters to the editor, guidelines, literature reviews, systematic reviews, meta-analyses, and summaries. Table 2 presents the inclusion and exclusion criteria used in this research.

\section{DATA ANALYSIS}

The extraction of data for the eligibility process was performed using a form specifically for systematic reviews prepared by the researchers in Excel $^{\circledR}$, in which the extracted data were added initially by one of the researchers, and then revised by another researcher. The data obtained from eligible studies were also added to a spreadsheet in the same software, in order to organize the results. The data extracted
TABELA 2. SUMMARY OF THE INCLUSION/EXCLUSION CRITERIA

\begin{tabular}{|c|c|}
\hline \multicolumn{2}{|l|}{ Inclusion criteria } \\
\hline Design & $\begin{array}{l}\text { Case reports } \\
\text { Case-control studies } \\
\text { Controlled clinical trials } \\
\text { Cohort Studies } \\
\text { Screening studies } \\
\text { Observational studies }\end{array}$ \\
\hline Location & No restrictions \\
\hline Language & No restrictions \\
\hline \multicolumn{2}{|l|}{ Exclusion criteria } \\
\hline Design & $\begin{array}{l}\text { Letters to the editor } \\
\text { Guidelines } \\
\text { Literature reviews } \\
\text { Systematic reviews } \\
\text { Meta-analyses }\end{array}$ \\
\hline Studies & $\begin{array}{l}\text { Unclear studies } \\
\text { Poorly described or inappropriate }\end{array}$ \\
\hline Type of publication & Only summary \\
\hline
\end{tabular}

Source: Prepared by the authors.

from the studies were analyzed descriptively, and the following were extracted: year of publication, place where the research was carried out, type of study design, assessments and tests performed, as well as the methods, used, and the results found. These studies had a score greater than 6 on the modified protocol by Python et al. ${ }^{30}$ to assess their quality.

\section{RESULTS}

Initially, 840 articles were identified, of which three qualified and passed to the stage of abstract assessment. Of these, two were excluded because they did not answer the guiding question. Thus, one article was eligible according to the Prisma ${ }^{29}$ criteria used for the development of this research. We proceeded to carefully read the study in full and, after applying the eligibility criteria, the study ${ }^{31}$ on the association between Kawasaki Disease and COVID-19 in children was selected to be the object of this analysis.

The study selected for this systematic review was a case study with descriptive analysis. In the analysis, they were categorized according to the theme investigated, Kawasaki Disease, and its possible association with the novel coronavirus.

The study ${ }^{31}$ was carried out on a female patient, 6 months of age, full-term, previously healthy, who initially attended the pediatric emergency care with fever, agitation, and refusal to eat. On the second day of fever, she developed an erythematous rash and, on the fourth day, persistent skin rash and possible mild congestion, but without coughing. In addition 
to these symptoms, the child presented irritability, limbus-sparing conjunctivitis, and chapped and dry lips. On the fifth day of fever, the child remained with limbus-sparing conjunctivitis, in addition to presenting prominent papillae of the tongue, maculopapular, polymorphic, throbbing rash, and swelling of the hands and lower extremities, thus meeting the classic criteria for KD. Initially, the patient was diagnosed with a viral infection. A chest X-ray showed a low opacity in the left lung, however, clinical laboratory examinations showed altered blood levels.

Due to the fever, possible mild congestion, as well as the radiographic chest findings, the child was referred to COVID-19 testing, although there was no history of contact with other patients or recent travels, and the family had been in isolation for a week. The night before the discharge, the tests for COVID-19 came back positive.

Table 3 shows the main characteristics described in the study included for analysis.

\section{DISCUSSION}

$\mathrm{KD}$ is an acute vasculitis of childhood and the main cause of acquired heart disease in children, with 50\% of the cases occurring in children younger than 2 years old and $80 \%$ in those younger than 5 years ${ }^{32}$. The child of the study selected for this review is at the beginning of the age group affected by the disease, 6 months old, and KD is rare in children younger than 6 months old'.

The diagnosis of KD is based on the observation of signs and symptoms such as high fever persistent for at least five days, in association with four of five diagnostic criteria, such as alterations in the oral cavity, conjunctival hyperemia, changes in the extremities, and cervical lymphadenopathy ${ }^{33}$. The exact cause of KD still remains unknown. The factor most considered up until now suggests contagion by various viral infections with an expansion of infectious agents, particularly in the period between winter and spring ${ }^{26}$.

However, although knowledge of its etiology is still incipient, studies have been developed in recent years. Recent research has described an association between viral respiratory infections and KD, ranging from $9 \%$ to $42 \%$ of patients DK with a positive test for viral respiratory infection within 30 days before the diagnosis of $\mathrm{KD}^{15,25,27}$.

In the study selected in this review, although there was evidence of a viral infection with positive results for COVID-19 in a child treated for KD, the association between the positive results and the configuration of KD was not established ${ }^{31}$. Because this is a case study, the data presented are initial and encourage further and more robust clinical research and analyses to elucidate findings for a better clinical implication.

After the study was published in a scientific journal in mid-April 2020, there was greater attention from researchers and pediatricians of various countries

TABLE 3. SUMMARY OF THE RESULTS FOUND IN THE ARTICLE INCLUDED IN THE REVIEW

\begin{tabular}{|c|c|c|c|}
\hline $\begin{array}{l}\text { Author/Year/Loca- } \\
\text { tion/Type of Study }\end{array}$ & Objective & Results & Conducts/Conclusion \\
\hline $\begin{array}{l}\text { Jones, et al. (2020) } \\
\text { United States } \\
\text { Case study }\end{array}$ & $\begin{array}{l}\text { Describe the case of a } \\
\text { pediatric patient diagnosed } \\
\text { with and treated for KD in } \\
\text { the context of confirmed } \\
\text { infection by COVID-19 }\end{array}$ & $\begin{array}{l}\text { *Body temperature: } 38.3^{\circ} \mathrm{C} \text { for over } 4 \text { days } \\
\text { *Complete blood count: CRP } 13.3 \mathrm{mg} / \mathrm{dl} \text {; } \\
\text { hyponatremia; normocytic anemia; hypo- } \\
\text { albuminemia; } \uparrow \text { erythrocyte sedimentation } \\
\text { rate } \\
\text { *Hemodynamic parameters: Sinus tachycar- } \\
\text { dia ( } 200 \text { bpm), and tachypnea } \\
\text { *Parameters of oxygenation and respiratory } \\
\text { assessment: SpO }-100 \% \text {; mild subcostal } \\
\text { retractions; small opacity in the left lung } \\
\text { base } \\
\text { *Echocardiogram: without evidence of cor- } \\
\text { onary dilation, without pericardial effusion, } \\
\text { and with normal ventricular and valvular } \\
\text { function. } \\
\text { *Testing for Influenza:negative } \\
\text { *Testing for Covid - } 19 \text { : positive } \\
\text { *Assessment with marked signs of: Irrita- } \\
\text { bility, conjunctivitis, skin rashes, dry and } \\
\text { chapped lips. Swelling in the hands and } \\
\text { lower limbs }\end{array}$ & $\begin{array}{l}\text { - Patient treated with a single dose of } 2 \mathrm{~g} / \\
\mathrm{kg} \text { of intravenous immunoglobulin (IVIG) } \\
\text { and a high dose of acetylsalicylic acid } \\
\text { (ASA } 20 \mathrm{mg} / \mathrm{kg} \text { four times a day) } \\
\text { - Clinical Course of mild COVID-19 } \\
\text { - Since this is a description of a single } \\
\text { case, more detailed studies on pediatric } \\
\text { patients diagnosed with COVID-19 are } \\
\text { required, mainly regarding its association } \\
\text { with KD. }\end{array}$ \\
\hline
\end{tabular}

Legend: $\mathrm{KD}$ = Kawasaki Disease; COVID-19 = coronavirus; $\mathrm{SpO}_{2}$ - Partial oxygen saturation; ${ }^{\circ} \mathrm{C}$ - degrees Celsius; bpm - beats per minute; $\uparrow$ high; $\mathrm{mg} / \mathrm{dl}$ - milligrams per deciliters Source: Jones, et al., 2020 . 
regarding the possible association between COVID19 and $\mathrm{KD}^{34}$.

On 4 May 2020, the department of health of the city of New York issued a health alert describing 15 cases of a multisystem inflammatory syndrome with characteristics of KD in children ${ }^{34}$. Despite the lack of details inherent to these types of reports, deciphering the exact nature and severity of the cases admitted in a hospital environment is still a challenge. Additionally, due to the pandemic scenario in which we are still living and the recent nature of the topic, studies under development have not yet been completed and published in scientific journals ${ }^{34}$.

A study developed by researchers from Bergamo, an Italian city widely affected by the COVID-19 epidemic, found an increase of 30 times in the incidence of Kawasaki Disease after the start of the epidemic. The children diagnosed during this period showed evidence of immune response to the virus, were older, had a higher rate of cardiac involvement, characteristics of macrophage activation syndrome, and required adjuvant treatment with steroids. The COVID-19 epidemic was associated with a high incidence of a severe form of DK. The authors also estimate that a similar outbreak of Kawasaki Disease can occur in the countries involved in the pandemic ${ }^{35}$.

At the time of hospital discharge of the patient described in the study, the World Health Organization had reported nearly 180,000 confirmed cases of COVID-19 globally, with 7,426 deaths ${ }^{9}$. Despite the growing number of cases reported, little is known about the infectious, clinical, and epidemiological aspects associated with COVID-19, particularly in the pediatric population ${ }^{36}$.

Up until now, the pediatric presentation known from COVID-19 infections encompasses a variety of signs and symptoms, such as fever, fatigue, myalgia, cough, sore throat, runny nose, congestion, and shortness of breath. In more severe cases, symptoms can include gastrointestinal alterations and patients can progress to respiratory failure, shock, coagulation dysfunction, and renal injury. In addition to the cases with clear and detectable signs and symptoms, completely asymptomatic infections can occur ${ }^{36}$. In

FIGURE 1. FLOWCHART OF STUDY SEARCH AND ANALYSIS

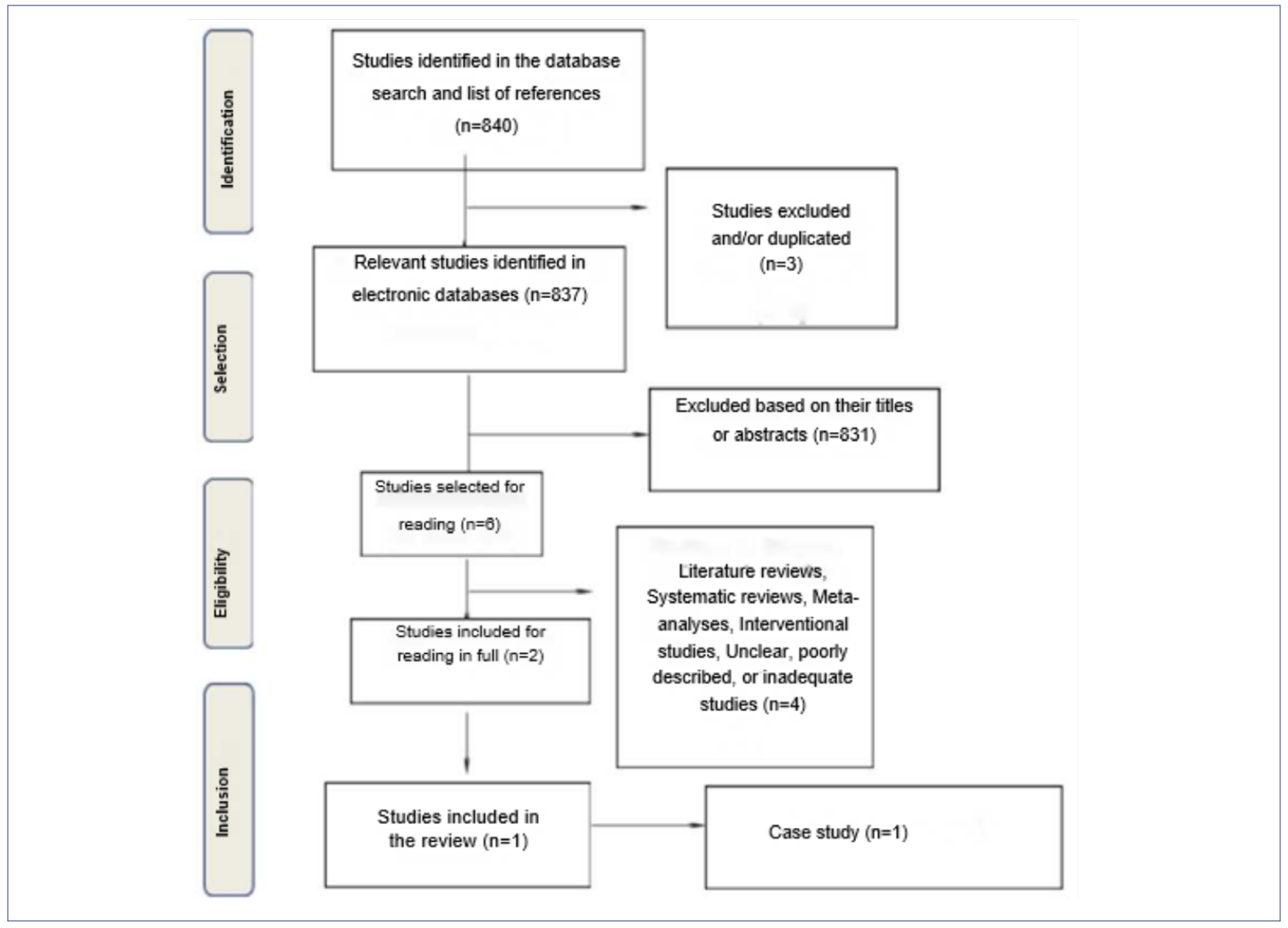

Source: Prepared by the authors. 
the patient of the study selected ${ }^{31}$, the symptoms that led professionals to request COVID-19 testing were mild fever, congestion, and the radiological findings, which showed low opacity in the left lung, with most of the symptoms characteristic of COVID-19 absent, which has also been reported in the literature ${ }^{36}$.

Although it is still early, the emergence of patterns that seem quite similar in several cities certainly points to a causal association between COVID-19 infection and KD. The alerts from Italy and France contain little data, and further publications will probably be released ${ }^{34}$.

At the moment, around 5,014,943 cases of COVID19 have been documented worldwide, with children also being infected with an increasing number of reported cases; however, with minimal load ${ }^{37}$.

Epidemiological data from many countries show that children are a small group of COVID-19 cases. Patients younger than 18 years old accounted for only $1.7 \%$ of the national population of cases in the USA, $1 \%$ of the cases in Holland, and $2.0 \%$ of a large observational cohort study in the United Kingdom ${ }^{37}$.

With respect to the COVID-19 infection, the clinical course, and presentation of the patient in the study were mild. Throughout hospitalization, she showed no remarkable respiratory symptoms with characteristic clinical signs of KD and was treated with a single dose of $2 \mathrm{~g} / \mathrm{kg}$ of intravenous immunoglobulin (IVIG) and a high dose of acetylsalicylic acid (ASA $20 \mathrm{mg} / \mathrm{kg}$ four times a day) in a hospital environment ${ }^{31}$. Both the clinical characteristics and the treatment diverged from the evidenced in a recent study that found major complications in children with KD, in addition to requiring adjuvant treatment with steroids $\mathrm{s}^{35}$.

Post-discharge recommendations for monitoring included echocardiography after 1-2 weeks and 4-6 weeks after the treatment ${ }^{31}$. The approach to the pediatric population with a clinical spectrum must still be clearly defined; patients who present fever alone or mainly involvement of other organs, such as gastrointestinal symptoms, might not be submitted to COVID-19 testing if this remains restricted to those with respiratory complaints.

The COVID-19 pandemic has been characterized by uncertainty. Faced with a severe pandemic, taking early actions in the absence of solid data is understandable and often necessary. With the increase of cases reported worldwide, data shows that it is plausible that associations between COVID-19 infections and other conditions could be found in the future ${ }^{34}$.

Although medical entities and researchers have increased their attention to the association between COVID-19 infections and possible complications in children, more detailed descriptions about the clinical course of this population are still necessary, mainly regarding its possible association with KD.

However, studies have already reported an association between viral respiratory infections and KD, in addition to finding a significant increase in the incidence of diseases like Kawasaki after the start of the epidemic, suggesting an association between the COVID-19 epidemic and the high incidence of a severe form of KD.

Finally, data shows that associations between COVID-19 infections and other conditions are likely to be found in the future.

\section{Author's Contribution}

All authors contributed equally to this work.

\section{RESUMO}

OBJETIVO: Apresentar evidências científicas com base em revisão sistemática da literatura (Prisma) avaliando a associação da Doença de Kawasaki (DK) e COVID-19 em crianças.

MÉTODOS: Para a seleção dos estudos foi utilizada a combinação baseada no Medical Subject Heading Terms (MeSH). Foram utilizadas as bases de dados Medline (PubMed), Lilacs, SciELO, Cochrane e Bireme.O período de busca dos artigos compreendeu os últimos dez anos (2010 a 2020).

RESULTADOS: Foram recuperados 840 artigos com potencial de inclusão, sendo que um respondeu aos critérios de inclusão e à pergunta norteadora que consistiu em avaliar a associação da Doença de Kawasaki e COVID-19 em crianças.

CONCLUSÃo: Um aumento significativo na incidência de doenças do tipo Kawasaki após o início da epidemia já foi relatado, sugerindo a associação entre a epidemia de COVID-19 e a elevada incidência de uma forma grave da DK. Contudo, mais estudos são necessários para conduzir a investigação da associação entre essas duas doenças.

PALAVRAS-CHAVE: Síndrome de Linfonodos Mucocutâneos. Infecções por coronavírus. Criança. Vasculite. Doença de Kawasaki. COVID-19 


\section{REFERENCES}

1. Agarwal S, Agrawal DK. Kawasaki disease: etiopathogenesis and novel treatment strategies. Expert Rev Clin Immunol. 2017;13(3):247-58

2. Rodrigues M, Oliveira C), Carvalho F, Silva H, Moreira C, Granja S, et al. Doença de Kawasaki e Complicações Cardiovasculares em Pediatria. Nascer e Crescer Birth and Growth Medical Journal. 2018; 27(1): 54-8.

3. Lin MT, Wu MH. The global epidemiology of Kawasaki disease: Review and future perspectives. Glob Cardiol Sci Pract. 2017; 3: 3-6.

4. Kim, BG. Reality of Kawasaki disease epidemiology. Korean J Pediatr. 2019; 62(8): 292-96.

5. Sharma D, Singh S. Kawasaki disease - A common childhood vasculitis Indian J Rheumatol. 2015; 10: 578-83.

6. Saguil A, Fargo A, Grogan S. Diagnosis and management of kawasaki disease. Am Fam Physician. 2015; 91(6): 365-71.

7. Castro AP, Costa CMI, Urbano, FML. Kawasaki disease. An Bras Dermatol. 2009;84(4):317-31.

8. Loomba, RS, Villarreal, E,Flores, S.COVID-19 and Kawasaki syndrome: should we really be surprised?. Cardiology in the Young. 2020; 1-5.

9. WHO: World Health Organization. Doença de coronavírus (COVID-19) Pandemia [internet]. 2020. [Acesso em: 7 maio 2020]. Disponível em: https://www.who.int/emergencies/diseases/novel-coronavirus-2019?gclid=CjwKCAjw4871BRAjEiwAbxXi29gEUGkT-x11583SIRVeCvzOYufu1EWhdMb60_9_G_ZOII69vN_5tRoCt_kQAvD_BwE.

10. Catalano-Pons C, Quartier P, Leruez-Ville M. Primary cytomegalovirus infection, atypical Kawasaki disease, and coronary aneurysms in 2 infants. Clin Infect Dis. 2005;41(5):53-6.

11. Shike H, Shimizu C, Kanegaye IT. Adenovirus, adeno-associated virus and Kawasaki disease. The Pediatric infectious disease journal. 2005;24(11):1011-14

12. Ferraz C, Cunha F, Mota TC, Carvalho JM, Simoes JS, Aparicio JM. Acute respiratory distress syndrome in a child with human parvovirus B19 infection. The Pediatric infectious disease journal. 2005;24(11):1009-10.

13. Turkay S, Odemis E, Karadag A. Kawasaki disease onset during concomitant infections with varicella zoster and Epstein-Barr virus. Journal of the National Medical Association. 2006;98(8):1350-52.

14. Sopontammarak S, Promphan W, Romanew S, Phetpisan S. Positive serology for dengue viral infection in pediatric patients with Kawasaki disease in southern Thailand. Circulation journal: official journal of the Japanese Circulation Society. 2008;72(9):1492-94.

15. Jordan-Villegas A, Chang ML, Ramilo O, Mejias A. Concomitant respiratory viral infections in children with Kawasaki disease. The Pediatric infectious disease journal. 2010;29(8):770-2

16. Huang $X$, Huang $P$, Zhang L. Influenza infection and Kawasaki disease.Rev Soc Bras Med Trop. 2015;48(3):243-8

17. Joob B, Wiwanitkit V. Kawasaki Disease in a 2-year-old Child with Dengue Fever: Correspondence. Indian journal of pediatrics. 2016;83(9):1054.

18. Hu P, Guan Y, Fan XC, Lu FY, Song LM. Incomplete Kawasaki disease induced by measles in a 6-month-old male infant. International journal of dermatology. 2016;55(1):34-36.

19. Jagadeesh A, Krishnamurthy S, Mahadevan S. Kawasaki Disease in a 2-yearold Child with Dengue Fever. Indian journal of pediatrics. 2016;83(6):602-3

20. Weng KP, Cheng-Chung Wei J, Hung YM. Enterovirus Infection and
Subsequent Risk of Kawasaki Disease: A Population-based Cohort Study. The Pediatric infectious disease journal. 2018;37(4):310-15.

21. Guleria S, jindal AK, Pandiarajan V, Singh MP, Singh S. Dengue-Triggered Kawasaki Disease: A Report of 2 Cases. J Clin Rheumatol. 2018;24(7):401-4.

22. Thissen $\mid B$, Isshiki $M$, laing $C A$ novel variant of torque teno virus 7 identified in patients with Kawasaki disease. PloS one. 2018;13(12):e0209683.

23. Wang |, Sun F, Deng HL, Liu RQ. Influenza A (H1N1) pdm09 virus infection in a patient with incomplete Kawasaki disease: A case report. Medicine. 2019;98(15):e15009.

24. Maggio MC, Cimaz R, Alaimo A, Comparato C, Di Lisi D, Corsello G. Kawasaki disease triggered by parvovirus infection: an atypical case report of two siblings. J Med Case Reports. 2019;13(1):104

25. $\mathrm{Kim} \mid \mathrm{H}, \mathrm{Yu} \|$, Lee |. Detection rate and clinical impact of respiratory viruses in children with Kawasaki disease. Korean J Pediatr. 2012; 55:470-3.

26. Chang LY, Lu CY, Shao PL, Lee PI, Lin M, Fan TY, Cheng AL, Lee WL, Hu J), Yeh S), Chang CC, Chiang BL, Wu MH, Huang LM. Viral infections associated with Kawasaki disease. I Formos Med Assoc. 2014; 113(3):148-54.

27. Turnier JL, Anderson MS, Heizer HR, Jone PN, Glode MP, Dominguez SR. Concurrent Respiratory Viruses and Kawasaki Disease. Pediatrics. 2015;136:e609-614.

28. Tersalvi G, Vicenzi M, Calabretta D, Biasco L, Pedrazzini G, Winterton D. Elevated troponin in patients with Coronavirus Disease 2019 (COVID-19): possible mechanisms. Journal of Cardiac Failure. 2020; 1-16.

29. Moher D, Shamseer L, Clarke M. Preferred reporting items for systematic review and meta-analysis protocols (PRISMA-P) 2015 statement. Syst Rev. 2015;4(1):1. Published 2015 Jan 1.

30. Pithon MM, Santanna LIDA, Baião FCS, Santos RL, Coqueiro RS, Maia LC. Assessment of the effectiveness of mouthwashes in reducing cariogenic biofilm in orthodontic patients: a systematic review. J Dent. 2015; 43:297-308

31. Jones GV, Milles M, Suarez D, Hogan AC, Yeh D,Segal B], et al. COVID-19 and Kawasaki Disease: Novel Virus and Novel Case. Hospital Pediatrics. Hospital Pediatrics. 2020; 1-11. Hosp Pediatr. 2020;10(6):537-540.

32. Rowley AH, Shulman ST. The Epidemiology and Pathogenesis of Kawasaki Disease. Front Pediatr. 2018;6:374.

33. Almeida RGD, Goldenzon AV, Rodrigues MCF, Sztajnbok FR, Elsas MICG, Oliveira SKFD. Perfil da doença de Kawasaki em crianças encaminhadas para dois serviços de reumatologia pediátrica do Rio de laneiro, Brasil. Bras J Rheumatol. 2010; 50(5): 529-38.

34. Schroeder, AR, Wilson KM, Ralston AL. COVID-19 and Kawasaki Disease: Finding the Signal in the Noise. Hosp Pediatr. 2020; doi: 10.1542/ hpeds.2020-000356

35. Verdoni L, Mazza A, Gervasoni A, Martelli L, Ruggeri M, Ciuffreda M, et al. An outbreak of severe Kawasakilike disease at the Italian epicentre of the SARS-CoV-2 epidemic: an observational cohort study. Lancet. 2020; 395:1771-8.

36. Dong $Y$, Mo X, Hu Y, et al. Epidemiological Characteristics of 2143 Pediatric Patients With 2019 Coronavirus Disease in China. Pediatrics. 2020; 145(6):e20200702.

37. Viner RM, Whittaker E. Kawasaki-like Disease: Emerging Complication During the COVID-19 Pandemic. Lancet. 2020;395(10239):1741-3. 